Aldo Ramírez Zamudio* José Luis Nolazco Cama"

Recibido: 9 de enero de 2020

Concepto de evaluación: 15 de abril de 2020

Aprobado: 13 de mayo de 2020

Artículo de investigación

(C) 2020 Universidad Católica de Colombia. Facultad de Ciencias Económicas y Administrativas. Todos los derechos reservados

* Ph.D. in Economics, Universidad Autónoma de Madrid; Director of the Center for Economics, Banking, and Finance, Department of Economics, Universidad de Lima, Av. Javier Prado Este S/N - Santiago de Surco, Lima 33, Peru. Email: aframire@ulima.edu.pe

(D) https://orcid.org/0000-0001-7509-3975

** M.Sc. in Economic Analysis, Universidad de Chile; Economist from the Universidad Agraria la Molina with a specialization in Applied Econometrics, Professor of Economics at the Universidad de Lima, Peru. Email: jnolazco@ulima.edu.pe

(D) https:// orcid.org/0000-0002-1727-8864

\section{Assessment of fiscal effort and voluntary tax compliance in Peru ${ }^{1}$}

\begin{abstract}
This study examines the fiscal effort and voluntary compliance in the payment of taxes in Peru, given that in 2014 , the Peruvian economy collected only $52.8 \%$ of its total tax potential. Through an experiment, the research shows that dissuasive policies only do not explain the whole phenomenon of tax compliance; on the contrary, some psychological factors, denoted in the literature as "tax morale", should also be considered in such study. Thus, if Peru expects to join the OECD (a goal for celebrating the bicentennial of its independence), it must improve tax compliance to standards equal to those of more developed countries; some non-dissuasive and low-cost public policies based on tax morale research may help to achieve this goal.
\end{abstract}

Keywords: tax burden, fiscal effort, tax morale.

JEL Classification: H32, H30, H26.

1 We are grateful to participants at the First International Congress of Behavioral Economics and Finance at the Universidad de Lima, Peru, in November 2018 for helpful comments and suggestions. We also gratefully acknowledge financial support from the Instituto de Investigación Científica (IDIC), Universidad de Lima, and helpful research assistance by Deyvi Abanto and Christie Awa, also at the Universidad de Lima. 


\section{Evaluación del esfuerzo fiscal y cumplimiento voluntario en el pago de impuestos en Perú}

\section{Resumen}

Este estudio examina el esfuerzo fiscal y el cumplimiento voluntario impositivo en Perú. Así, en 2014, la economía peruana recaudó solo el $52.8 \%$ de su potencial total. Luego, a través de un experimento se demuestra que las políticas disuasivas no explican por sí solas el cumplimiento tributario; por el contrario, los factores psicológicos, agrupados por la literatura como "moral fiscal", deben considerarse en dicho estudio. Por lo tanto, si Perú espera unirse a la OCDE (ya que es un objetivo para celebrar el bicentenario de su independencia), debe mejorar el cumplimiento tributario con estándares similares a los de los países más desarrollados, y algunas políticas públicas de bajo costo diseñadas sobre la investigación de la moral fiscal pueden ayudar a conseguir este objetivo.

Palabras clave: carga tributaria, esfuerzo fiscal, moral tributaria. 


\section{INTRODUCTION}

Peru desires, by the date of its bicentennial celebrations in 2021, to join the Organisation for Economic Co-operation and Development (OECD), an institution comprising the countries with the highest incomes. However, its current social and economic indicators are still considerably behind those of the member nations of the OECD. To achieve its goal, the country must be able to support greater public spending in a diversity of areas ranging from public infrastructure to the consolidation of institutions.

This public spending would be primarily supported by tax revenue, which has been increasing in Peru since the beginning of the 1990s, mostly due to consistent economic growth and macroeconomic stability, as well as to a set of specific reforms in tax administration, including the rationalization of the tax system, which reduced the number of taxes, while upholding the principles of sufficiency, efficiency, equity, and simplicity.

Indeed, Peru has to a certain extent modernized its tax system and has achieved a relative amount of efficiency by using improved technology and an autonomous and centralized administration system. However, at present, tax collection in Peru is still clearly unsatisfactory, far behind OECD standards, and tax policy is still focusing on measures geared towards broadening the tax base and resolving what appears to be the main underlying problem: tax evasion (MEF, 2015).

But before marking tax evasion as the main cause for unsatisfactory tax collection, it is necessary to consider other elements that might affect it. On this point, Rossignolo (2017) says that besides evasion, fiscal exemptions also have an important negative role in tax collection in Latin America because they somehow allow tax avoidance (see also Jiménez, Gómez Sabaini \& Rossignolo, 2012). Therefore, it is important to start by calculating the level of fiscal effort or how close the country is to its potential tax collection; then, if fiscal effort approaches potential collection, we may associate its insufficient level to an intrinsic low capacity of contribution (Rossignolo, 2017).

But, on the other hand, and mentioning in advance some of our findings, if the level of fiscal effort is low in comparison to potential tax collection, tax evasion turns out to be the most important element to focus on, and this is certainly a consequence of an inadequate management of a country's fiscal capacities. 
Most studies regarding this phenomenon in several Latin American countries, and particularly in Peru, have mainly focused on finding the optimal sum to be collected in order to finance services necessary for providing support and stimulating economic growth that would be both inclusive and sustainable over the long term (Davoodi \& Grigorian, 2007; Fenochietto \& Pessino, 2013; Caceres et al., 2015; IMF, 2015). Even more, other studies along these lines have evaluated the possibility of directly burdening the extraction of non-renewable resources (Mendoza, 2011; Sanborn \& Dammert, 2013). However, despite all the research that has been conducted, no specific study exists regarding Peru (and very few involving other countries in the region) that examines the phenomenon of tax evasion from the perspective of individual decisions of economic agents. In other words, why would many people choose not to comply with the payment of their taxes, in view of that the government has already implemented various types of measures to increase tax collection?

This question is important because it is not enough simply to collect more; rather, it is fundamental to know how to do so. This involves knowing how people think about the government, as well as understanding data that may be related to their decisions to contribute. This information may eventually allow for the development of public policies that provide people with positive incentives to pay their taxes voluntarily.

Even though tax systems may include many types of taxes (direct, indirect, on property, etc.) and any individual tax may have consequences on economic efficiency and income distribution (Mirrlees, 1971; Alesina \& Angeletos, 2005), this experimental study focuses on the individual income tax. There are many reasons to do so. First, it is easier to set an experiment to test individual decisions in an environment closely related to personal income tax. Second, income tax is the least inefficient and unfair tax in the current tax system because, as established in most places, it is a direct and progressive tax, which means that it burdens more when a person has more income. Therefore, if a tax system aims to be fair to its citizens and redistribute wealth, which is a necessity in Latin American countries given their income concentration and inequality (Rossignolo, 2017), then it should be more intensive regarding the income tax than other indirect taxes, such as the value-added tax (VAT) or some sales taxes that apply tax on the value of a good or service no matter the income of the subject who pays for it, which are regressive in terms of income distribution (see also Alesina \& Angeletos, 2005). Third, personal income tax was only $11.35 \%$ of total tax revenues in Peru in 2015 (MEF, 2018). If we add this to the corporate income tax, direct taxes amount to $37 \%$ of total revenues in comparison to indirect 
taxes that represent more than $50 \%$. This is probably the clearest hint of why it is important to look for the causes of the country's unsatisfactory tax collection in the income tax and, more specifically, in the personal one.

In summary, this study aims to measure the fiscal effort in general and, in consequence, the approximate amount of tax evasion in Peru, ${ }^{1}$ as compared to other similar countries in the region and to the OECD countries. In this specific aspect, as we will see, the country's overall fiscal effort and the personal income tax is far below the OECD standards, which turns to be the main reason to design an experiment where individual subjects may reveal their will to contribute. Therefore, our second goal is to present the results of a one-shot experiment in Peru in 2016, in order to get some insights on the profiles and opinions of Peruvian citizens, as well as to show that non-pecuniary motives to contribute to the government affect compliance, which would defy the claim found in neoclassical literature that tax evasion is primarily explained by the intensity of dissuasion measures (Schnellenbach, 2010). If these non-pecuniary motives do exist, some simple and low-cost public policies could be designed and implemented to stimulate citizens to contribute, which would improve tax collection without direct and high-cost enforcement measures like audits or sophisticated controls. After all, people contribute by themselves, but also run businesses from the smallest to the biggest, making decisions every day. In the same vein, experiments search for incentives that influence people's decisions. Therefore, even though data obtained from lab experiments or from most field studies cannot be extrapolated to the whole population given their relatively small samples, it can certainly be useful to extend research and contrast various research hypotheses (Levitt \& List, 2007).

Regarding compliance, neoclassical theory on tax evasion has been tested and challenged ${ }^{2}$ since the 1980 s, primarily in developed countries, and the results have demonstrated that the application of dissuasive measures does not satisfactorily explain the relatively low levels of evasion observed in these countries. Thus, "behavioral economics"—adding some elements of individuals' decision-making process, like psychological factors, among others-has contributed to a better understanding of this problem. Indeed, various works have found that altruism, sense of pride, reciprocity, and other related aspects appear to influence tax compliance. All these factors together form part of a wider spectrum recently known in the literature as "tax morale".

\footnotetext{
1 There are different approaches to calculate evasion of the main taxes in the system, but all of them result in big rates.

2 Primarily in the form of social experiments.
} 
In addition, previous works on tax evasion in the region were carried out using letters containing different kind of messages, aimed to find out any effect on taxpayer compliance (Del Carpio, 2014), or surveys that tried to detect people's motivations to evade/comply (Ortega, Ronconi \& Sanguinetti, 2016). However, the testing method preferred by behavioral economists is experimentation; in general, the use of experiments has several advantages over the use of letters or surveys since experimentation achieves a higher degree of abstraction, thus eliminating the possibility that answers might be given without any motive or according to the context, which results in the collection of more natural and realistic data. Precisely, our contribution to the literature is to run, for the first time in Peru, a simple oneshot experiment to find out whether subjects are willing to contribute to Peruvian government when we separate the voluntary decision to give from dissuasion. Our hypothesis is that taxpayers, and agents in general, also show other motives to contribute to the government than only those enforced by the law, even in economic environments in which corruption and the level and quality of public services and goods are well below the standards of developed countries.

First, we assess fiscal effort in Peru in comparison to countries in the region and other countries that belong to the OECD. The results of the current study indicate that Peru collects only $52.8 \%$ of its total potential (less than $20 \%$ of its GDP), well below the maximum collection possible according to its current economic and social characteristics, which is equivalent to $36 \%$ of its GDP. After running an experiment following the design of López-Pérez and Ramírez-Zamudio (2018), the study finds that (on average) people are willing to donate more to the Peruvian government (S/.4.7) than to a well-known and well-reputed non-profit institution used as a control group (S/. 3.2). Since donations to the government are purely voluntary and we control for dissuasion, the results show that dissuasion is not the only fundamental element that explains tax compliance.

The structure of the remainder of this paper is as follows: The next section explains stylized facts related to taxation in Peru. However, given that the taxation system and revenue collection have changed over time, it was necessary to conduct an overall analysis of the evolution of taxation in Peru and determine how the country compares to the main economies in Latin America (LA6), as well as to developed economies (OECD). Then, the study presents a review of the current literature. The following two sections explain the methodology used in this social experiment and briefly analyze the results obtained, respectively. Finally, we present our conclusions. 


\section{STYLIZED FACTS: THE EVOLUTION OF TAXATION IN PERU}

One of the most useful measures to compare tax compliance among countries is the ratio of tax revenues as percentage of the Gross Domestic Product (GDP). Henceforth we call this the "tax-to-GDP ratio". Tello (2002) indicated that at the beginning of the 1980 s, due to a certain degree of stability with respect to the tax-to-GDP ratio, the collection of the selective consumer tax (ISC, for its acronym in Spanish) - especially as applied to fuel-began to take on greater importance, whereas the collection of the income tax (IT) ${ }^{3}$ and the value-added tax known in Peru as general sales tax (IGV, for its acronym in Spanish) began to register a decrease. In the case of IT, an excessive number of processing steps and multiple deductions hindered its administration. This situation revealed the necessity for a reform of the tax collection system.

At the beginning of the 1990s, Peru experienced a severe political and economic crisis, which lead to the implementation of a structural reform plan, including a tax reform. Between 1992 and 1993, special regimes of IGV, IT, and many exemptions that hindered the supervisory work of the recently created National Superintendency Figure 1.

Tax revenue as a percentage of GDP in Latin America and the OECD

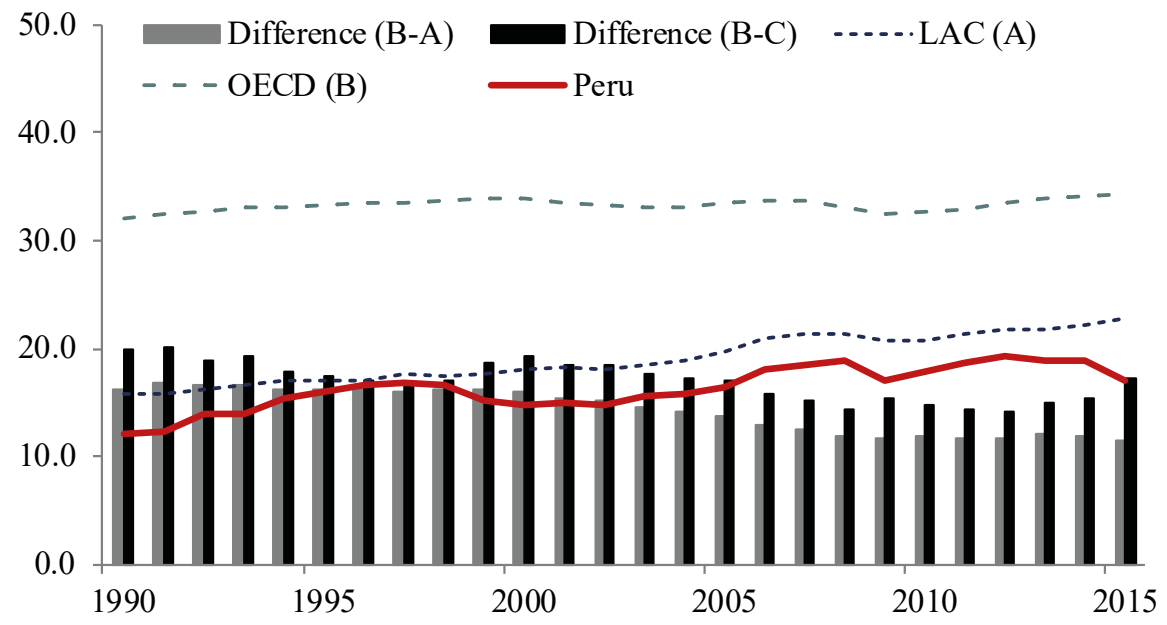

Note: LAC economies refer to the average (not weighted) of 19 countries in Latin America (without Peru). OECD economies represent the average (not weighted) of the 34 member countries of the OECD. Chile and Mexico are also considered in this group. Source: OECD/CEPAL/CIAT/BID (2017).

3 Very similar in nature to the value-added tax that most European and Latin-American countries have. 
of Tax Administration (SUNAT, for its acronym in Spanish) were eliminated. At the beginning of the first Fujimori government in 1990, a stabilization program was implemented, resulting in strict fiscal and monetary discipline. The fiscal policy aimed to significantly reduce the public deficit by means of increasing tax revenues and establishing an implicit rule regarding a spending limit. To do so, a series of structural reforms were carried out, among which the reform of the taxation system stands out (Durand \& Thorp, 1998).

This tax reform was implemented in three phases. The goal of the first phase was the rationalization and simplification of taxes, seeking to facilitate the work involved in tax administration, as well as to modify or eliminate those that resulted in economic distortions (Baca, 2000). The second phase, which began in 1992, aimed to achieve a simpler, more efficient and permanent taxation system; however, although the number of tax categories decreased significantly, some regimes that created complexities for both taxpayers and tax collectors persisted (the so called "simplified" and "special regimes") (Tello, 2002).

It is relevant to note that the tendency to increase tax revenue in Peru during the period from 1990 to 2013 follows a behavioral pattern similar to that observed in all Latin America and appears to be mainly the result of favorable macroeconomic conditions and, to a lesser degree, of changes implemented in tax regimes and the strengthening of tax administrations, conditions that did not exist during the 1980s (OECD/ECLAC/CIAT/IDB, 2017). Thus, the gap between tax revenue in Peru and the remaining countries in Latin America as compared to the OECD has been diminishing. In 2000 , this gap equaled 19.8 percentage points, and by 2013 , it decreased by $4 \%$.

It must be added that another reason for the increase in tax revenue in Latin America appears to be fiscal reforms implemented at the end of the 1980s and beginning of the 1990s, beginning with the introduction of the value-added tax (IGV). Along these lines, subsequent reforms related to this focused on attempting to extend and reinforce it by means of raising the tax rate and widening the tax base. Accordingly, in the 1990s, the collection of IGV as a percentage of GDP in Peru was only $1.5 \%$, but by 2013 it increased considerably to $6.8 \%$ (see Figure 2).

\section{Current Tax Structure and Its Evolution}

Nevertheless, when all taxes are considered, the volume of tax collection in Peru continues to be relatively low despite all the efforts that have been deployed, representing 
Figure 2.

$$
\text { Central government revenues according to source (\% of GDP) }
$$

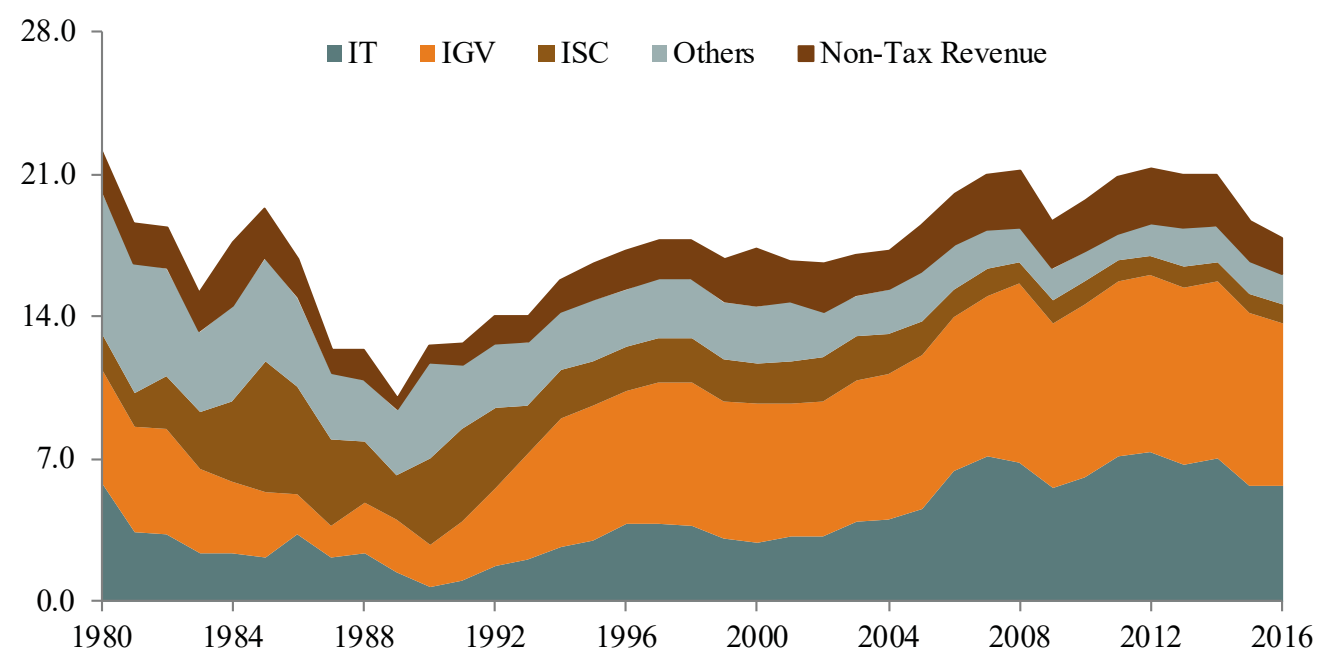

Source: Central Reserve Bank of Peru.

only 16.4\% of GDP in 2013 and 16.6\% in 2014 (not including non-tax revenues). In comparison, the average for Latin America in 2013 was 23.4\% of GDP and 34.1\% for the OECD. It is also worth noting that the gap between tax collection in Peru and in the OECD has diminished only marginally over the last 25 years (1990-2014). Therefore, despite Peru's achievement of increasing its tax revenue by approximately 5.1 percentage points and partly closing its tax collection gap regarding the OECD, this apparent tendency, which is similar to that reported by larger Latin American countries, appears to be primarily a result of favorable macroeconomic conditions.

Although the tax revenue gap in Peru and the main Latin American countries (Chile, Colombia, Uruguay, and Brazil) as compared to the OECD has been narrowing, its progress since 2000 has been very slow (Figure 3). In addition, although tax collection has increased, Peru's heavy dependence on indirect ${ }^{4}$ taxes results in a regressive ${ }^{5}$ system, clearly contrasting with developed countries that depend pri-

4 Tax imposed on certain transactions, goods or events. Examples include value-added tax, sales tax, excise duties, stamp duty, services tax, registration duty, and transaction tax.

5 In these systems, tax collection as a proportion of income is lower as the contributor's income increases, meaning that the system affects families with smaller incomes more than those with larger incomes. 
Figure 3.

Tax-to-GDP ratio in 2015 (\% of GDP)

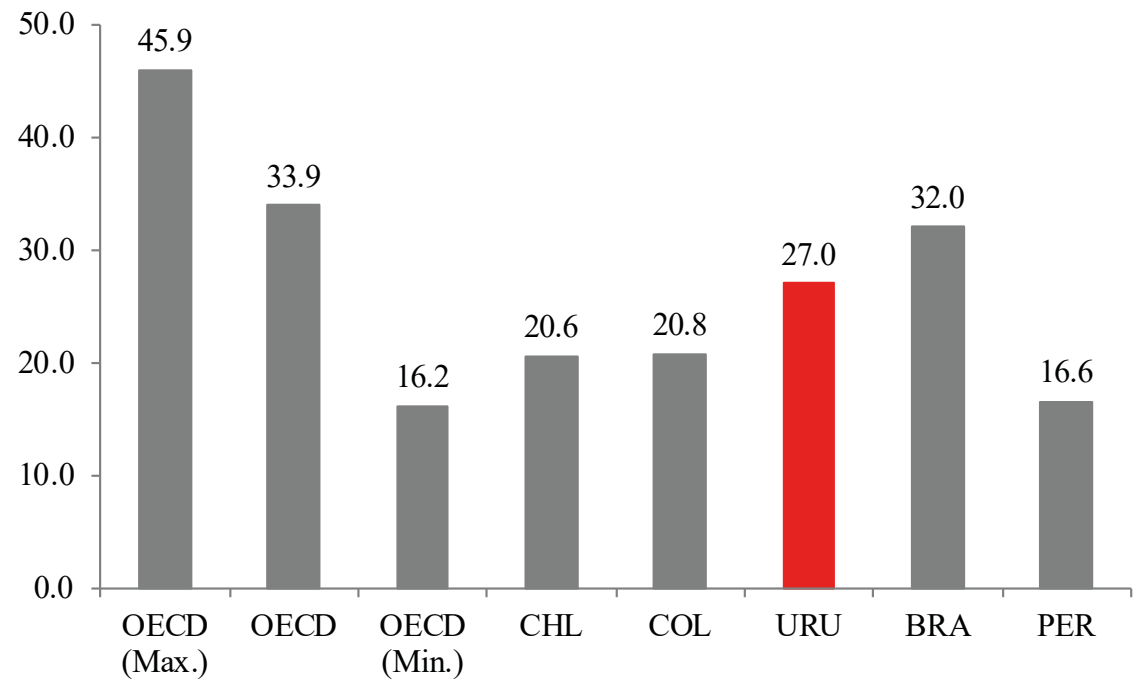

Source: OECD/CEPAL/CIAT/IDB (2017).

marily on direct ${ }^{6}$ taxes (Figure 4). Thus, as reported by the OECD (2015), the biggest source of revenue in Peru in 1990 was taxes on specific goods and services (54\%), in contrast to both OECD countries (13\%) and the LA6 (27\%). By 2013, 42.9\% of tax revenue came from direct taxes, such as income tax, temporary tax on net assets, and the simplified unified regime (RUS, for its acronym in Spanish) for small tax-paying entities, but the remaining $57.1 \%$ of the revenue still depended on indirect taxes.

It should be noticed that one of the greatest advantages of the tax-to-GDP ratio is that it is easily obtained and can be used as a reference for comparing taxes among countries, allowing an analysis of the gaps that Peru must close with regard to the other countries.

Also, tax burden is the estimate of tax revenue as compared to variables that are related to various economic structures, institutional indicators, income levels, and country-specific characteristics, among others. Finally, fiscal effort is simply the ratio between the real value and its estimated potential for tax income with respect to the GDP. Therefore, fiscal effort is considered high as it approaches the

6 Direct taxes are taxes imposed on income, capital gains, and net worth. Gift tax, death duties, and property tax are also considered direct taxes. 
Figure 4.

Collection of direct taxes in 2015 (\% of GDP)

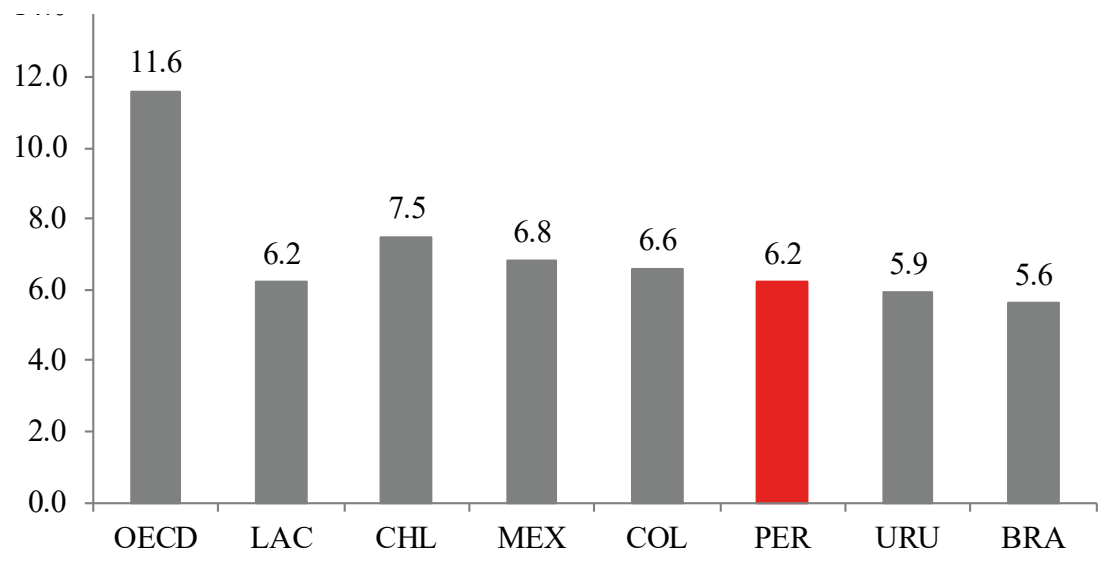

Source: OECD/CEPAL/CIAT/IDB (2017).

value 1 . Numbers below 1 indicate that there still exists potential for the country to increase its tax revenue. ${ }^{7}$

Even tough collection of direct taxes as a percentage of GDP in Peru is equal to the region's average, it is approximately only a half of that of the OECD. However, the biggest issue is that this amount is mostly explained by what appears to be a very heavy burden on corporate income tax, which is $22 \%$ of total revenues (8.9\% in average for the OECD), while the personal one is only $11 \%$ (MEF, 2018), being very far from the OECD's average of $24.4 \%$ (OECD/ECLAC/CIAT/IDB, 2017). This poor performance may well be explained by an income distribution with a low median income, but it must be highlighted that in 2017, 72.5\% of the total labor force in Peru was informal, which means that they were not registered in social security nor paid personal income tax (INEI, 2018). Therefore, it seems that Peru should concentrate its efforts on improving the personal income tax collection through a serious labor force formalization.

\section{Determinants of Tax Revenue}

In view of these definitions, this section shows the results of our econometric estimations in order to calculate the tax burden and fiscal effort for 111 countries (among

$7 \quad$ The calculations for fiscal effort among the countries presented in the current study are not a substitute for an in-depth analysis of taxes, focusing on one specific country. 
which 21 are countries in Latin America and 29 belong to the OECD) for the period between 1990 and 2014, using ordinary least squares (OLS) in panel data (Pessino \& Fenochietto, 2010; Fenochietto \& Pessino, 2013). This methodology estimates fiscal effort using econometric specification similar to the one proposed by Pessino and Fenochietto (2010), who evaluate possible determinants of tax revenue with regard to GDP (R) as follows:

$$
\log \left(\mathrm{R}_{\mathrm{it}}\right)=\alpha_{0}+\alpha_{1} \log \left(\mathrm{Y}_{\mathrm{it}}\right)+\alpha_{2} \log \left(\mathrm{Y}_{\mathrm{it}}\right)^{2}+\alpha_{3} \mathrm{AC}_{\mathrm{it}}+\alpha_{4} \mathrm{VA}_{-} \mathrm{a}_{\mathrm{it}}+\alpha_{4} \log \left(\mathrm{I}_{\mathrm{it}}\right)+\mathrm{v}_{\mathrm{it}}-\mathrm{u}_{\mathrm{it}}
$$

in which $\log (\mathrm{R})$ is the logarithm of the tax revenue as a percentage of the GDP of the country " $\mathrm{i}$ " in the year " $\mathrm{t}$ ", $\log (\mathrm{Y})$ is the logarithm of GDP per capita ${ }^{8}$ (in thousands of US\$). Logarithmic transformation is useful for calculating fiscal effort (Pessino \& Fenochietto, 2010). AC is a measure of trade openness (exports plus imports as a percentage of GDP), VA_ $\mathrm{a}_{\mathrm{it}}$ is the added value of agriculture as a percentage of GDP, and $\mathrm{I}_{\mathrm{it}}$ is an institutional indicator defined as the Corruption Perception Index, ${ }^{9} \mathrm{v}$ is the error term, and $\mathrm{u}$ represents inefficiency whose proxy is the gap between what is actually collected and what could potentially be collected in each country. The literature review (Tanzi \& Davoodi, 1997; Davoodi \& Grigorian, 2007) sketched out above helped to identify the variables to include in the regression for the analysis on tax revenue potential.

The results of specification (1) are shown in Table 1, which contains the estimates for the entire period from 1994 to 2012. First, the Breusch-Pagan test indicates that the null hypothesis that the OLS estimate is adequate ${ }^{10}$ is not rejected. Second, the estimated coefficients exhibit the expected signs and are statistically significant at $5 \%$. This suggests that as improvements are made in tax reforms and each country makes an effort to simplify their tax system and work towards greater efficiency and a smaller tax burden, especially regarding income taxes, income level appears to be less important for determining the tax-to-GDP ratio. Finally, the magnitude of the coefficient of the institutional variable appears to support this argument. Therefore, in addition to conventional determinants of tax revenues, the quality of institutions and governance (measure for the Corruption Perception Index) are important factors behind the poor tax collection in Peru and many other countries. These factors are

8 Also included is the logarithm of the square of the GDP per capita as an explanatory variable, since it can capture the non-linearity between tax collection and income per capita; as a result, $\alpha_{1}$ is expected to be positive and $\alpha_{2}$ negative.

9 The Corruption Perception Index was normalized so that it admits values between 0 and 1, 0 indicating a perception that the country is extremely corrupt, and 1 representing the opposite perception.

10 Therefore, the Hausman test is not necessary since it is used to compare between fixed effects and random effects in panel data. 
Table 1.

Determinants of tax capability, 1994-2012

(OLS panel regression models)

\begin{tabular}{|c|c|}
\hline \multicolumn{2}{|c|}{ Dependent Variable: Log (Tax Revenue/GDP) } \\
\hline Constant & $3.34^{* * *}$ \\
& $(0.17)$ \\
\hline Log GDP per capita & $0.17^{* * *}$ \\
\hline & $(0.05)$ \\
\hline Log GDP per capita2 & $-0.06^{* * *}$ \\
\hline Openness toward trade (\% of GDP) & 0.001 ) \\
\hline Added value of agriculture (\% of GDP) & $(0.003)$ \\
\hline Log Corruption Perception Index & $-0.07^{* * *}$ \\
\hline Wald chi2 (5) & $-3.002)$ \\
\hline Prob > chi2 & $(0.63)$ \\
\hline Log Likelihood & 92.72 \\
\hline Breusch-Pagan (p-value) & 0.000 \\
\hline
\end{tabular}

Note: The values in parentheses represent robust standard errors. All variables were obtained from the World Development Indicators and the Quality of Government Standard Dataset. It is important to mention that the OLS panel regression model is using unbalanced data.

${ }^{*} \mathrm{p}<0.1,{ }^{* *} \mathrm{p}<0.05,{ }^{* * *} \mathrm{p}<0.01$

Source: authors' elaboration.

thought to influence tax revenue through their contribution to tax evasion, improper tax exemptions, and weak tax administration (Tanzi \& Davoodi, 1997).

It should be mentioned that the inclusion of the quadratic term of the GDP per capita variable has the expected sign during the period 1994-2012, and also for the period from 1994 to 2001, being significant only in the latter sub-sample. In this case, the behavior of the institutional variable through the signs or product significance is as expected. The results found in this study corroborate those found by Davoodi and Grigorian (2007), although the current study exhibits more evidence for the effect of institutions on tax collection. In general, countries with a greater income, a greater openness toward trade, and excellent institutions are associated with greater tax revenues.

\section{Fiscal Effort and Tax Evasion}

Using the estimated coefficients from Table 1, the fiscal effort was calculated for all the countries studied for the years 1994-2014. As seen in Table 2, Peru collects 
below its potential, and although the measures adopted by the government over the last decade attempted to increase collection, the fiscal effort of its tax system is not only below its potential but is also below the average for the LA6 countries. Based on these estimations, it can be seen that in 2014 Peru collected only $52.8 \%$ of its collection potential, that is, well below the maximum collection level given its economic and social characteristics. The current study estimates that this collection level is equivalent to approximately $36 \%$ of the country's total GDP (Fenochietto \& Pessino, 2013; Caceres et al., 2015).

This low fiscal effort is not a result of low tax rates, which are slightly higher than average for the region, but related to non-compliance, among other issues (Pessino \& Fenochietto, 2010; Fenochietto \& Pessino, 2013). For that matter, although SUNAT calculated that the gap caused by non-compliance to IGV has diminished over the last years and exemptions still exist as a result of the opening of the economy in the 1990s, the low levels of tax collection appear to be related primarily to the high rate of tax evasion.

This rate is estimated to be $38 \%$ for IGV and $48 \%$ for IT, placing Peru among the economies in the region with the highest levels of tax evasion (OECD, 2015). Finally, the relative operational inefficiency of SUNAT also appears to negatively contribute to the low levels of tax collection. ${ }^{11}$

It is common to assume that in order to collect more taxes, they should be raised, but the evidence appears to indicate the opposite. After studying the relationship between income tax collection and its maximum rate for the period 20072013, it was found that although Peru and the other LA6 economies have higher maximum IT rates (above 25\%) than the OECD countries (where maximum rates are about 11\%), they collect less (in percentage of GDP) (Gómez \& Morán, 2016). On the other hand, another reason for the low level of tax collection may be attributed to a smaller tax base and the high level of informality in Peru's economic activities. For example, Gómez and Morán (2016) demonstrate that activities that take place informally constitute a potential form of tax evasion since they do not pay taxes, thus contributing to low levels of tax collection in a sample of LAC countries.

Precisely, in Peru, informal workers have been estimated as $72 \%$ of the total labor force, which, therefore, would prove to be the primary source of high levels of income tax non-compliance, reaching $48 \%$ according to the OECD. Although Peru

11 According to the OECD, the administrative cost of containing 100 units of net income was greater than $1.5 \%$ of the total, a figure which is greater than that of similar institutions in Latin America (less than 1.5\%) and in OECD countries (less than $1 \%$ ). 
Fiscal effort and tax potential, 2014

\begin{tabular}{|c|c|c|c|c|}
\hline & $\begin{array}{c}\text { Total collected } \\
\text { (\% of PBI) }\end{array}$ & $\begin{array}{c}\text { GDP per capita } \\
\text { PPP (US } \mathbf{2 0 1 1} \text { ) }\end{array}$ & Fiscal effort & $\begin{array}{c}\text { Tax potential (\% of } \\
\text { GDP) }\end{array}$ \\
\hline Brazil & 29.6 & 15,222 & 0.87 & 34.0 \\
\hline Chile & 20.2 & 21,801 & 0.55 & 36.7 \\
\hline Colombia & 20.1 & 12,304 & 0.61 & 33.0 \\
\hline Peru & 19.0 & 11,324 & 0.53 & 35.9 \\
\hline Uruguay & 27.1 & 19,316 & 0.74 & 36.6 \\
\hline OECD (minimum) & 19.7 & 16,160 & 0.30 & 65.7 \\
\hline OECD & 34.1 & 34,894 & 0.78 & 43.9 \\
\hline OECD (maximum) & 48.6 & 42,483 & 0.96 & 50.6 \\
\hline
\end{tabular}

Note: The OECD country that collects the most (least) is Denmark (Mexico). For Brazil, Chile, Colombia, Uruguay, and the OECD, the tax potential values obtained belong to the findings of Caceres et al. (2015). For Peru, the values are estimates based on the data obtained in Table 1. Source: authors' elaboration, including data from Caceres et al. (2015).

has improved its tax collection since 1990 due to its tax reform, it is evident that the country is still far from being able to compare itself with the largest LA6 countries, not to mention the developed economies of the OECD.

Consequently, it may be claimed that modifying the tax structure is not adequate for improving tax collection, and that the reduction of informality in economic activities appears to be the next logical step to get closer to the standards of developed countries. Given the importance of the institutional indicator in these estimations, the government's weakness regarding this issue is one of the main factors responsible for its poor performance in tax collection. To be estimated, institutionality consists of prevailing factors, such as the existence of efficient tax systems, a lower tax burden (especially in the case of income tax), and situations in which the income level becomes less important in determining taxes, among others. Therefore, the action of the government-also an institution - would affect individual decisions to pay taxes, given that a low level of institutionality stemming primarily from the high level of informality is a significant root of the problem. Aspects involving social relationships among individuals, the authorities, and other individuals (in other words, aspects that are clearly psychological) appear to play a role in explaining the high levels of tax evasion in Peru that, until now, has been scarcely studied. The state of the art of the topic, as well as the theoretical framework of the present study described in the sections that follow shed light on some of these unknown factors. 


\section{THEORETICAL FRAMEWORK}

Research on tax evasion as an economic phenomenon can be traced back to the seminal work of Allingham and Sandmo (1972), based on the theory of the economics of crime developed by Becker (1968); this view emphasizes the fundamental role of dissuasion in enforcing tax compliance. However, the role of dissuasion has been widely discussed, since the models based on it have been mostly refuted empirically, a fact that has given birth to an abundant literature exploring the importance of psychological factors in paying taxes.

For example, after extensively reviewing neoclassical literature on tax evasion, Andreoni, Erard and Feinstein (1998) indicate the need to incorporate elements of morality and social dynamics in order to explain empirical evidence that finds a considerable number of voluntary compliers not predicted by conventional theory. They mention moral norms and sentiments that lead individuals to make decisions regarding their tax reports. Factors like justice (equity) and tax system complexity, as well as the opinion or perception of individuals regarding public spending (goods and services) and corruption in the government can affect voluntary compliance (see also Rabin 1998).

These deviations from what neoclassical theory predicts have been extensively studied from the 1970's by experimental economics, and even though the use of experiments in social sciences is still debated, their results do not pretend to be generalizable in any circumstance. Indeed, Levitt and List (2007) claim that although lab experiments create by necessity an environment far from being representative of real life, they allow for causal inference under their specific experimental conditions, which is extremely useful in confirming a cause-effect relationship that researchers look for in theory testing.

On the same vein, if we recall that $72.5 \%$ of the total labor force was informal in 2017 (INEI, 2018), we may look for the individual's motivations to contribute (or not) using experimental techniques; this is the main reason why the experiment was set as it is in this work. If it is possible to identify some important subjects' motivations or characteristics, they may allow further research and probably the design of better and cheaper public policies to incentivize voluntary tax compliance.

Indeed, looking for evidence provided by experiments, Bazart and Bonein (2014) demonstrate the importance of reciprocity between individuals and the government through a laboratory experiment in which the following two types of unequal situations are settled: (i) the first one they call "vertical" (government sets different treatments for two identical taxpayers), and (ii) the second, which they 
call "horizontal" (taxpayers differ with respect to their voluntary compliance due to differences of income). Their results support the existence of both negative and positive reciprocity in both the vertical and horizontal case. On the same token, Schnellenbach (2010) claims that taxpayers evade taxes as a form of retaliation against a government that is not cooperative nor just. Similarly, an individual's tax evasion increases if he or she believes that other taxpayers also evade taxes.

Based on their results, Alm, McClelland and Schulze (1992), who also conducted experiments involving voluntary compliance, suggest that individuals ascribe a higher value to public goods that were financed by their taxes. See also Charness and Rabin (2002), who claim that individuals set aside their desire to sacrifice themselves in order to reach a just result when others fail to sacrifice themselves as well, punishing thus unjust behavior. Their data support the theory that positive reciprocity appears to be of little importance, whereas negative reciprocity is of great importance. Moreover, the suspicion that taxpayers evade taxes in order to re-establish fairness when they perceive that they are being treated unfairly is corroborated by Fortín, Lacroix and Villeval (2007), who ran an experiment and discovered that individuals who were taxed at a greater rate than the average tax rate for their group tended to increase their levels of evasion as the gap between their tax rate and the average tax rate increased (negative reciprocity).

Little research has been carried out on the importance of these psychological factors in Latin America. One of the most notable works is that of Ortega, Ronconi and Sanguinetti (2016), who conducted a study that specifically examined the personal attitudes of Latin American individuals regarding tax compliance. Using surveys administered in 17 Latin American cities, the authors evaluated the relationship between government performance and individual willingness to pay taxes, using instrumental variables (IV) and ordinary least squares (OLS). Their results indicate that on average those participating in the survey claimed that they were willing to correspond (reciprocate) positively if the government improved the quality of its services (social work, fighting crime, health, and education), as well as its institutions demonstrated improvement in areas such as transparency, corruption, and effectiveness in collecting taxes.

In the specific case of Peru, the IV National Survey on Corruption Perception in 2010 reveals relevant data concerning voluntary compliance. It was found that $79 \%$ of those interviewed about their perception of the corruption in the government stated that they were highly or moderately inclined to evade if they were certain that 
it could not be detected, and $82 \%$ of them admitted that they did ask for invoices in order to avoid paying the value-added tax (IGV), despite the fact that these same people considered corruption to be the main problem in the country, as well as tax evasion as one of its most frequent manifestations.

Hirsh (2011) used the results from the Survey on Tax Culture conducted in Peru among more than 8,000 households and found that although most Peruvians consider that paying taxes is good because it is the right thing to do and it demonstrates responsible citizenship, they also indicate that they would stop paying taxes if they had the opportunity to do so without being discovered. Furthermore, the collected data indicate that more than one third of those who took the survey were opposed to paying taxes, giving a set of reasons, which the author decided to call "conditional cooperation". These reasons are as follows: (i) I do not want to give up money in exchange for nothing; (ii) no one else pays either; (iii) others do it, so it is not necessary for me to do it; (iv) no one forces me to do it. The study also indicates that $54 \%$ of the working population does not pay personal income tax and justifies this decision by citing factors such as corruption present in the State (56\%), lack of income (55\%), high rates imposed (52\%), poor use of resources on the part of the government (52\%), and the perception that they will not benefit from public spending or investment (46\%), among other factors. Finally, for the question regarding what they considered to be the main actions or responsibilities of the State that would increase their willingness to pay taxes, participants in the survey indicated the following: a greater use of resources for social programs (80\%), a decrease in corruption levels (76\%), concentration of State actions on the provision of services (74\%), improvements regarding the equity of tax policy (66\%), and improvements in the management of public administration (60\%), among other factors.

Finally, as we stated before, this literature refers to the individuals' decisions, because the focus is on personal decisions, whether they be in one's own name (such as in the case of income tax or value-added tax) or as representative of a small business ${ }^{12}$ (profit taxes), making individual decisions, in reaction to either individual or group incentives. The realm of corporate decision-making or that of large companies is beyond the scope of the present work, primarily because the most common form of non-compliance for these entities is tax avoidance, not tax evasion, which is the phenomenon that the present study seeks to understand better.

12 They constitute the great majority of companies in Peru. 


\section{METHODOLOGY}

Following the methodology of López-Pérez and Ramírez-Zamudio (2018), a simple experiment was conducted in which the participating subjects were divided into the following two groups: (1) treatment (with the government) and (2) control (a nonprofit institution). Each group contained 60 individuals, ${ }^{13}$ totaling 120 subjects. The experiment was carried out on two different dates, each of which comprised two sessions at two different times. On October 29, 2016, two sessions were carried out, the first with the treatment group (30 individuals) from 9 a.m. to 10:30 a.m., and the second with the control group from 11 a.m. to 12:30 p.m. The other two sessions were carried out on November 12 of the same year, at the same times, and in the same manner: the first session being used for the treatment group (30 individuals), and the second for the control group (30 individuals). We run the experiment in two different dates only for logistical reasons, but the protocol and questionnaires ${ }^{14}$ were identical for both.

The subjects of the experiment ${ }^{15}$ were a group of individuals chosen from the inhabitants of the city of Lima, recruited randomly and stratified by gender, socioeconomic level, and age, representing the target public who would be obligated to pay taxes. ${ }^{16}$ Once we had the 120 subjects, we assigned them to each group (control and treatment) randomly, but according to their gender, age, and socioeconomic level. Again, it is important to precise that we do not claim that the results of this experiment can be extrapolated to the whole population since the sample is not big enough and the insights obtained by experiments have their own interpretations and utility, most of the times conditioned to the experimental design (Kagel \& Roth, 1997; Levitt \& List, 2007; List, Sadoff \& Wagner, 2010). The guiding principle in the selection of these individuals is the discovery of factors that explain their voluntary compliance towards the government, without necessarily considering the type of tax (as has already been mentioned, the study deals with the individual income tax).

Thus, the experiment began with each chosen subject being given 20 Peruvian soles (approximately 6 \$US) as a fixed income (mobility payment) for their participation. Subsequently, they were offered an additional payment of 30 soles (approximately 9 \$US); of these remaining 30 soles, the subjects in the treatment group had

13 Based on what was suggested by List, Sadoff and Wagner (2010), the optimal sample size for the treatment and control groups of this study is 51 and 31 individuals, respectively. For more details concerning the optimal sample size, see appendix 1.

14 Appendix 2 available here: https://drive.google.com/open?id=15roHowWdqFQflurL6PQIiG0DmM91_D9A

15 The sample structure may be seen in Appendix 1.

16 What is known in Peru as PEA or the Economically Active Population, that is, individuals whose age and capabilities allow them to work, whether dependently or independently. 
to decide whether they would voluntarily donate part of the sum to the Peruvian government, whereas in the control group (non-profit institution) the subjects had to decide whether they would voluntarily donate part of the 30 soles to the Peruvian League against Cancer. To test whether people are willing to voluntarily give money to the government, we chose the League against Cancer because it is a well-known and well-reputed non-governmental organization (NGO), which regularly runs public and national fundraisings to fund cancer treatments for people in need. We thought that it was the right choice to test people's attitudes towards these very different institutions in terms of reputation and usefulness for the common citizen.

The end profit of the subjects was equivalent to 20 mobility soles, plus the initial provision of 30 soles minus the donation. In this experiment, the focus was on very simple decision-making criteria, involving one single decision per individual, that is, the act of donating, which was considered a proxy of voluntary compliance, in other words, a payment made without any type of coercion.

In general, for both groups (treatment and control), each session was carried out in the following manner: the subjects participating in the experiment were given instructions, a decision sheet, and a questionnaire in which they had to answer a series of questions useful for the study; the experiment was carried out in a classroom and the subjects were conveniently separated in such a way as to prevent communication among them.

The instructions were read, and the subjects proceeded to fill out a sheet called "elicitation," where they indicated the size of their donation, and subsequently filled out a questionnaire developed by the researchers. It must be noted that data from the questionnaire was collected after the subjects had made their decision regarding their donation, and this decision could not be changed later. The aim was to capture their beliefs (prejudices or pre-conceived ideas) in a natural and almost unconscious manner according to the incentive provided (provision). The subjects in the experiment were then paid in private by an assistant, who was in a separate room and did not share any details with them.

The main goal of this experiment was to determine whether, by controlling for dissuasion (that is, removing it completely from the experimental environment) and isolating the decision in a completely voluntary context, donations proved to be different from zero. These results allow us to support that dissuasion is not necessarily a deciding factor in voluntary compliance; positive donations can be subsequently 
associated with the perceptions and opinions of the subjects who participated in the experiment, which were collected in the questionnaire. ${ }^{17}$

After the conclusion of each session, the experimenters and two of the participants (who acted as witnesses) deposited anonymously the amount of donations in an account of the Peruvian Public Treasury ${ }^{18}$ (Banco de la Nación, account number 00000-299294). The anonymous deposit to the Peruvian League against Cancer was made in the same way in the Banco de Crédito del Perú (account number 193-110188-0-80). Each subject's payoff equals the initial endowment minus the donation, plus 20 soles of show-up fee.

\section{RESULTS}

Table 3 presents the descriptive statistics for the main variables of the experiment. The first two variables are donation to the Peruvian government (treatment) and to the non-profit institution (control), in which we observe that individuals (on average) are more willing to donate to the Peruvian government (S/. 4.7) than to the non-profit institution (S/. 3.2).

Regarding perceptions of the distribution of public spending, subjects in both groups believe that the national budget is primarily (41.5\%) used to pay the salaries of civil servants, $35.2 \%$ is aimed to finance infrastructure, and $25.8 \%$ is aimed to social programs. The average level of religiosity is 5.2 over 10 , the average age among all participants was 39 years, and the average political inclination was 6.02, where 1 indicates the extreme left and 10 the extreme right, which means that, on average, the subjects in the experiment lean slightly toward the right of the political spectrum.

Also, regarding personal beliefs about the main explanation of one's income in life (where 0 indicates a fundamental role played by chance and influences, and 10 means pure effort), the average score given by the subjects is 7.4; in other words, on average, the participants believe that one's income in life is primarily a result of personal effort.

Talking about the participation of the government in the economy (where 1 indicates lack of agreement and 10 indicates strong agreement), the average is 6.4, indicating that, on average, the subjects accept that the government takes on a more active role. With regard to whether they believe that the government is controlled in the interest

17 Please consult appendix 1 for these and other details from the experiment.

18 Since Peruvian tax authority is only federal, all taxes go to a central account which is that we chose to make the deposit. 
Aldo Ramírez Zamudio • José Luis Nolazco Cama

Table 3.

Descriptive statistics of the main variables of the experiment

\begin{tabular}{|c|c|c|c|c|c|c|}
\hline \multirow[b]{2}{*}{ Variables } & Control & Treat. & Total & Treat. & Control & Total \\
\hline & Avg. & Avg. & Avg. & $\begin{array}{l}\text { Std. } \\
\text { Dev. }\end{array}$ & $\begin{array}{l}\text { Std. } \\
\text { Dev. }\end{array}$ & $\begin{array}{l}\text { Std. } \\
\text { Dev. }\end{array}$ \\
\hline Donation (S/.) & 3.2 & 4.7 & 3.95 & 2.9 & 4.7 & 3.8 \\
\hline Percep. of gov. spending - social (\%) & 26 & 25 & 25.8 & 0.14 & 0.18 & 0.16 \\
\hline Percep. of gov. spending - infrastructure (\%) & 34.3 & 36 & 35.2 & 0.16 & 0.18 & 0.17 \\
\hline Percep. of gov. spending - payment of salaries (\%) & 39 & 44 & 41.5 & 0.21 & 0.21 & 0.21 \\
\hline Average age (years) & 40 & 38 & 39 & 7.87 & 8.8 & 8.4 \\
\hline Level of religiosity (1: little, 10: extreme) & 4.96 & 5.4 & 5.2 & 2.66 & 2.75 & 2.7 \\
\hline Number of children & 1.63 & 1.28 & 2 & 1.51 & 1.07 & 1.3 \\
\hline Number of national political news viewings (0-7) & 2.88 & 2.96 & 2.9 & 1.03 & 0.88 & 0.9 \\
\hline Political spectrum (1: left, 10: right) & 5.96 & 6.07 & 6.02 & 2.09 & 1.9 & 2 \\
\hline What does income depend on? (0: chance, 10: effort) & 7.53 & 7.3 & 7.4 & 2.7 & 2.9 & 2.8 \\
\hline Percep. about trust (1: never trust, 10: always trust) & 3.4 & 3.23 & 3.3 & 2.42 & 2.04 & 2.2 \\
\hline $\begin{array}{l}\text { Whether distribution should be equal } \\
\text { (1: do not agree, 10: strongly agree) }\end{array}$ & 6.75 & 5.3 & 6 & 3.09 & 3.2 & 3.2 \\
\hline $\begin{array}{l}\text { Whether the government should participate in the } \\
\text { economy (1: do not agree, 10: strongly agree) }\end{array}$ & 6.4 & 6.4 & 6.4 & 2.96 & 2.9 & 2.9 \\
\hline $\begin{array}{l}\text { Whether a democratic economy grows less } \\
\text { (1: do not agree, 10: strongly agree) }\end{array}$ & 4.75 & 4.4 & 4.6 & 3.13 & 2.9 & 3 \\
\hline $\begin{array}{l}\text { Belief concerning how gov. is controlled } \\
\text { (1: for the interests of a few, 10: works for the people) }\end{array}$ & 3.9 & 3.5 & 3.7 & 2.7 & 2.9 & 2.9 \\
\hline $\begin{array}{l}\text { Whether the government provides adequate public } \\
\text { education services (1: yes, } 0: \text { no) }\end{array}$ & 0.26 & 0.3 & 0.3 & 0.45 & 0.46 & 0.5 \\
\hline $\begin{array}{l}\text { Whether the government provides adequate health } \\
\text { services }(1: \text { yes, } 0: \text { no) }\end{array}$ & 0.12 & 0.12 & 0.1 & 0.32 & 0.32 & 0.3 \\
\hline $\begin{array}{l}\text { Whether the government provides adequate public } \\
\text { safety services (1: yes, } 0: \text { no) }\end{array}$ & 0.08 & 0.1 & 0.1 & 0.28 & 0.3 & 0.3 \\
\hline $\begin{array}{l}\text { How much should high-income individuals pay in taxes } \\
\text { as compared to low-income individuals } \\
\text { (1: much less, 5: much more) }\end{array}$ & 3.75 & 3.32 & 3.5 & 1.5 & 1.3 & 1.2 \\
\hline $\begin{array}{l}\text { Opinion concerning previous government performance } \\
\text { (1: dismal, 10: excellent) }\end{array}$ & 2.8 & 3.05 & 2.9 & 1.8 & 1.8 & 1.8 \\
\hline $\begin{array}{l}\text { Support of the new government } \\
\text { (1: do not support it, } 10 \text { : support it entirely) }\end{array}$ & 6.02 & 6.25 & 6.1 & 2.9 & 3.2 & 3 \\
\hline $\begin{array}{l}\text { Willingness to pay more taxes for higher-quality public } \\
\text { services }(1: \text { yes, } 0: \text { no) }\end{array}$ & 0.7 & 0.7 & 0.7 & 0.47 & 0.46 & 0.5 \\
\hline
\end{tabular}

Source: authors' elaboration. 
of a few $(=1)$ or is working for the people $(=10)$, the average is 3.7 , indicating that, on average, the participants believe that the government is being controlled by personal interests. In turn, considering the performance of the previous government 1 = dismal, $10=$ excellent), the average is 2.9 , indicating that, on average, the subjects believe that the performance of the previous government was very poor.

To the question concerning whether they support the new government $(1=$ do not support, 10 = support it entirely), the average is 6.1, which indicates support from the majority, although not very pronounced. Finally, regarding the question on whether they would be willing to pay more taxes in exchange for better public services $(1=$ yes, $0=$ no), the average is 0.7 , indicating that the majority of subjects would be willing to pay more taxes in exchange for receiving better public services.

Table 4 divides the donations between the treatment and control groups, according to socioeconomic level, education level, and gender. Participants in the treatment group (government) tend to donate more (S/. 4.7) than to the non-profit institution (S/. 3.2); this pattern maintains for different socioeconomic and education levels, and genders.

Table 4.

Average donation (S/.) according to group

\begin{tabular}{|c|c|c|}
\hline & Treatment & Control \\
\hline Donation & 4.7 & 3.2 \\
\hline \multicolumn{3}{|c|}{ According to socioeconomic level ${ }^{18}$} \\
\hline$A$ and $B$ & 5.9 & 4.3 \\
\hline $\mathrm{C}$ & 4.8 & 2.6 \\
\hline $\mathrm{D}$ & 3.6 & 3.6 \\
\hline \multicolumn{3}{|l|}{ According to education level } \\
\hline Finished primary school & 1 & 3.2 \\
\hline Finished secondary school & 4.8 & 3 \\
\hline Technical higher education & 4.3 & 2.4 \\
\hline University higher education & 6 & 4.4 \\
\hline \multicolumn{3}{|l|}{ According to gender } \\
\hline Female & 5.1 & 3.3 \\
\hline Male & 4.5 & 3.2 \\
\hline
\end{tabular}

Note: The treatment group represents the average donation to the Peruvian government, and the control group represents the average donation to the non-profit institution.

Source: authors' elaboration.

19 Market research companies classify people according to some variables like income, access to private health insurance, properties, etc. in five categories (A to E), "A" is the highest category in terms of income and the other variables; this is what they call "socioeconomic level" (APEIM, 2017). 
All socioeconomic levels prefer to donate more to the government, and the same can be observed for gender. However, some heterogeneity is observed in donations grouped by education level, where the lowest education level is the only one in which donations are higher for the non-profit institution. Overall, however, more is donated to the government than to the non-profit institution.

In order to determine whether statistically significant differences exist between the treatment and control groups regarding donations made to the government and to the non-profit institution, a nonparametric Kolmogorov-Smirnov test ${ }^{20}$ was conducted, the results of which are shown in Table 5.

Table 5.

Differences in donation between the treatment and control groups: Nonparametric Kolmogorov-Smirnov test

\begin{tabular}{|l|c|c|c|c|c|c|}
\hline & \multicolumn{2}{|c|}{ Entire sample } & \multicolumn{2}{c|}{ Experiment 1 } & \multicolumn{2}{c|}{ Experiment 2 } \\
\hline & Difference & p-value & Difference & p-value & Difference & p-value \\
\hline Combined K-S & 0.133 & 0.660 & 0.333 & 0.071 & 0.133 & 0.952 \\
\hline
\end{tabular}

Source: authors' elaboration.

These results indicate that it is not possible to rule out a null hypothesis that the distribution of the donations of both groups are equal. This is because the probabilities are greater than 0.05 . Therefore, both groups (treatment and control) prove to be equal in terms of the statistical distribution.

Then we test the López-Pérez and Ramírez-Zamudio (2018) hypothesis about the importance of dissuasion and confirm that it does not appear to be a determining factor in the voluntary payment of taxes. In fact, the above experiment isolates the elements of tax morale related to donation by controlling for dissuasion so that donation should be statistically equal to zero in the absence of dissuasion. This may be verified in Table 6, where donation is statistically different from zero, even in the complete absence of dissuasion.

As we stated before (see also Levitt \& List, 2007), we do not pretend to extrapolate these results to the whole context of voluntary compliance regarding income tax, not even to Peru, but only to provide some interesting insights to be explored afterwards. Finally, more research confirming these findings may result in the design

20 Nonparametric tests are chosen rather than a regression in differences since the latter estimate assumes a normal distribution, which cannot be secured in the data obtained. 
Table 6.

Analysis of the null hypothesis that donation is equal to zero

\begin{tabular}{|c|c|c|c|c|}
\hline Variable & Analysis sample & Average & $\begin{array}{c}\text { Standard } \\
\text { deviation }\end{array}$ & $\begin{array}{c}H_{0} \text { : donation }=0 \\
H_{1} \text { : donation } \neq 0\end{array}$ \\
\hline \multirow{3}{*}{ Donation } & All & 3.94 & 0.36 & $\operatorname{Pr}(|T|>|t|)=0.00$ \\
\cline { 2 - 5 } & Treatment & 4.67 & 0.60 & $\operatorname{Pr}(|T|>|t|)=0.00$ \\
\cline { 2 - 5 } & Control & 3.22 & 0.37 & $\operatorname{Pr}(|T|>|t|)=0.00$ \\
\hline
\end{tabular}

Note: The results indicate that the null hypothesis that the average of donations for all cases is equal to zero is rejected at $5 \%$.

Source: authors' elaboration.

of low-cost public policies to stimulate voluntary compliance since it appears that people do not refuse to contribute, but their decisions are based on factors that government or tax administrations can manage or improve.

\section{CONCLUSIONS}

One of the main problems that limits public spending in Peru is undoubtedly tax non-compliance. Thus, despite efforts made over the last twenty-five years, this work estimates that Peru collects only $52.8 \%$ of its potential (less than $20 \%$ of its GDP), which means that it falls far below the maximum amount the country could collect according to its economic and social characteristics (at least 36\% of its GDP). This places Peru below the average in Latin America and very far from the standards of the OECD.

The experiment demonstrates, among other results, that people (on average) are willing to donate more to the Peruvian government (S/. 4.7) than to the nonprofit institution used as control (S/.3.2). Since donation is completely voluntary and controls for dissuasion, the results of this study indicate that dissuasion is not the only fundamental explanatory element in the payment of taxes, thus contradicting the claims of neoclassical literature.

Since no individual participated in more than one session in any of the groups (control or treatment), and both groups were selected in the same way and are statistically equal, it is probable that "moral licensing" ${ }^{21}$ could explain why subjects

21 Moral licensing can be defined as "the situation when under the threat that their next action might be (or appear to be) morally dubious, individuals can derive confidence from their past moral behavior". 
donate less to the League against Cancer. Indeed, if they feel that national donation campaigns for the League are frequent, they can donate less in this situation, given that they donate regularly. Other explanation may be that people could think that the government is more important and that, after receiving more donations, it would eventually finance the more limited activities of the League; these issues would be interesting to test in future research.

The sociodemographic data obtained among other elements may provide us with the ability to build a taxpayer profile. It would be interesting to see more experiments of this type done in order to enrich our knowledge of the problem. These findings, which are based on an experiment following that of López-Pérez and Ramírez-Zamudio (2018), contradict the fundamental role of dissuasion and also suggest that psychological factors are important in the decisions of individuals to voluntarily comply with tax payment. Consequently, the experiments should be repeated, preferably using the same form described in this study, in order to discard problems inherent to the experiment process, such as false consensus, lack of motivation to decide as a result of relevant information, little amount of reflection that might have resulted in the decisions of individuals, and other unexpected distortions, among others.

Even so, several probable recommendations arise for public policy, which must be carefully considered given what has been explained in previous paragraphs. For example, it is likely that an improvement in the image of authorities and in the transparency of public administrations may prove to be important to enhance the voluntary compliance of taxpayers. All mentioned facts must be confirmed through specific studies.

Likewise, the government should take the first steps to demonstrate to its citizens that it is, in fact, working for the common good, since evidence seems to indicate that these measures, although complex to define in detail and clearly beyond the scope of this work, would prove to be very effective regarding the lack of resources that most tax administrations have to face. 


\section{REFERENCES}

1. Alesina, A., \& Angeletos, G. M. (2005). Fairness and Redistribution. The American Economic Review, 95(4), 960-980. https://doi.org/10.1257/0002828054825655

2. Allingham, M., \& Sandmo, A. (1972). Income Tax Evasion: A Theoretical Analysis. Journal of Public Economics, 1(3-4), 323-338. https://doi.org/10.1016/0047-2727 (72)90010-2

3. Alm, J., McClelland, G. H., \& Schulze, W. D. (1992). Why do people pay taxes? Journal of Public Economics, 48, 21-38. https://doi.org/10.1016/0047-2727(92)90040-M

4. Andreoni, J., Erard, B., \& Feinstein, J. (1998). Tax compliance. Journal of Economic Literature, 36, 818-860.

5. Asociación Peruana de Empresas de Inteligencia de Mercados (APEIM). (2017). Niveles Socioeconómicos 2017. Lima: APEIM. http://apeim.com.pe/wp-content/ uploads/2019/11/APEIM-NSE-2017-1.pdf

6. Baca, J. (2000). El ancla fiscal: la reforma tributaria. In Abusada, R., Du Bois, F., Morón, E. \& Valderrama, J. (Eds.), La reforma incompleta (pp. 163-218). Lima: Universidad del Pacífico.

7. Bazart, C., \& Bonein, A. (2014). Reciprocal relationships in tax compliance decisions. Journal of Economic Psychology, 40(1), 83-102. https://doi.org/10.1016/j. joep.2012.10.002

8. Becker, G. (1968). Crime and Punishment: An Economic Approach. Journal of Political Economy, 76(2), 169-217.

9. Caceres, C., Cevik, S., Fenochietto, R., \& Gracia, B. (2015). The Day After Tomorrow: Designing an Optimal Fiscal Strategy for Libya. Journal of Banking and Financial Economics, 2(4), 32-50. https://doi.org/ 10.7172/2353-6845.jbfe.2015.2.3

10. Charness, G., \& Rabin, M. (1992). Understanding Social Preferences with Simple Test. The Quarterly Journal of Economics, 117(3), 817-869.

11. Davoodi, H., \& Grigorian, D. (2007). Potential vs. Fiscal effort: A Cross-Country Analysis of Armenia's Stubbornly Low Tax Collection. IMF Working Paper 07/106.

12. Del Carpio, L. (2014). Are the neighbors cheating? Evidence from a social norm experiment on property taxes in Peru. Mimeo, INSEAD.

13. Durand, F., \& Thorp, R. (1998). Tax Reform: An Analysis of the SUNAT Experience. In Crabtree, J., \& Thomas, J. (Eds.). Fujimori's Peru: The Political Economy (pp. 379408). London: ILAS.

14. Fenochietto, R., \& Pessino, C. (2013). Understanding Countries: Fiscal effort. IMF Working Paper 13/244.

15. Fortín, B., Lacroix, G., \& Villeval, M. (2007). Tax evasion and social interactions. Journal of Public Economics, 91(11-12), 2089-2112. https://doi.org/10.1016/j. jpubeco.2007.03.005 
16. Gómez, J., \& Morán, D. (2016). Evasión tributaria en América Latina: nuevos y antiguos desafíos en la cuantificación del fenómeno en los países de la región. Santiago: CEPAL - Serie Macroeconomía del Desarrollo N 172.

17. Hirsh, N. (2011). La creación y afianzamiento del concepto de ciudadanía fiscal: los programas de educación fiscal. Lima: Superintendencia Nacional de Administración Tributaria.

18. Instituto Nacional de Estadística e Información (INEI). 2018. Producción y empleo informal en el Perú. Cuenta Satélite de la Economía Informal 2007-2017. Lima: INEI. Retrieved from: https://www.inei.gob.pe/media/MenuRecursivo/publicaciones_digitales/ Est/Lib1589/libro.pdf

19. International Monetary Fund (IMF). (2015). Peru: Selected Issues. Retrieved from https://www.imf.org/external/pubs/ft/scr/2015/cr15134.pdf

20. Jiménez, J., Gómez Sabaini, J., \& Rossignolo, D. (2012). Imposición a la renta personal y equidad en América Latina. Nuevos desafíos. Macroeconomía del Desarrollo, 119.

21. Kagel, H., \& Roth, A. (1997). The Handbook of Experimental Economics. Princeton: University Press.

22. List, J., Sadoff, S., \& Wagner, M. (2010). So you want to run an experiment, now what? Some simple rules of thumb for optimal experimental design. NBER Working Paper Series 15701.

23. Levitt, S., \& List, J. (2007). What Do Laboratory Experiments Measuring Social Preferences Reveal about the Real World? The Journal of Economic Perspectives, 21 (2), 153-174. https://doi.org/ 10.1257/jep.21.2.153

24. López-Pérez, R., \& Ramírez-Zamudio, A. (2018). Giving Money to the Inca: Experiments and Theory on Social Norms and Tax Compliance in Peru. Documentos de Trabajo de Economía 18/07. Facultad de Ciencias Empresariales y Económicas: Universidad de Lima. http://www.ulima.edu.pe/node/9639

25. Mendoza, W. (2011). Tax Policy as Applied to Minerals and Petroleum: Theory, Experiences, and Proposal of a Policy for Peru. Lima: Center for Economic and Social Research (CIES).

26. Ministerio de Economía y Finanzas (MEF). (2015). Marco Macroeconómico Multianual 2016-2018. Lima: MEF. https://www.mef.gob.pe/contenidos/pol_econ/marco_macro/ MMM_2016_2018.pdf

27. Ministerio de Economía y Finanzas (MEF). (2018). Cuenta General de la República 2018. Tomo I. Lima: MEF. https://www.mef.gob.pe/contenidos/conta_publ/2018/ comp_tributario2018_tomo1.pdf

28. Mirrlees, J. A. (1971). An Exploration in the Theory of Optimal Income Taxation. Review of Economic Studies, 38, 175-208.

29. Ortega, D., Ronconi, L., \& Sanguinetti, P. (2016). Reciprocity and Willingness to Pay Taxes: Evidence from a Survey Experiment in Latin America. Economía, 16(2), 55-87.

30. Organisation for Economic Co-operation and Development (OECD). (2015). MultiDimensional Review of Peru: Volume I: Initial Assessment. Paris: OECD Development Pathways. 
31. OECD/ECLAC/CIAT/IDB. (2017). Revenue Statistics in Latin America and the Caribbean: 1990-2015. Paris: OECD Publishing. https://www.oecd.org/tax/tax-policy/ revenue-statistics-latin-america-caribbean-brochure.pdf

32. Pessino, C., \& Fenochietto, R. (2010). Determining countries' fiscal effort. Revista de Economía Pública, 195(4), 65-87.

33. Rabin, M. (1998). Psychology and Economics. Journal of Economic Literature, 36(1), $11-46$.

34. Rossignolo, D. A. (2017). El esfuerzo fiscal en los países de América Latina y el Caribe. Finanzas y política económica, 9(2), 215-247. https://doi.org/10.14718/rf\&pe.v9i2.1827

35. Tanzi, V., \& Davoodi, H. (1997). Corruption, Public Investment, and Growth. IMF Working Paper 97/139.

36. Tello, J. (2002). Elaboration of an Indicator of fiscal impulse. Lima: Center for Economic and Social Research.

37. Sanborn, C., \& Dammert, J. (2013). Extracción de recursos naturales, desarrollo económico e inclusión social: Perú. Prepared for Americas Quarterly. Documento de Investigación 13/14, Centro de Investigación de la Universidad del Pacífico. http:// www.as-coa.org/sites/default/files/MiningReportPeru2013.pdf

38. Schnellenbach, J. (2010). Vertical and horizontal reciprocity in a theory of taxpayer compliance. International Studies Program Working Paper 07-26. 


\section{APPENDICES}

\section{APPENDIX 1}

\section{Data sheet for tax experiment}

This social experiment was conducted on two different dates, on October 29 and on November 12, 2016, each of which included two sessions. It follows López-Pérez and Ramírez Zamudio (2018) and its purpose was to investigate the voluntary compliance of citizens in the Lima Metropolitan Area regarding the payment of taxes. In order to do so, two groups were formed, each containing 60 individuals; one group was called the treatment group and the other the control group. The treatment group was the subject of the experiment itself and measured the willingness of subjects to donate a portion of the money given to them to the Peruvian government. The purpose of the control group was to determine whether the hypotheses and/or predictions of the study actually occurred. This was possible because both groups were statistically similar, the difference being that the institution that would receive the donations of the control group was the Peruvian League against Cancer.

Both groups were formed in order to determine the willingness of individuals to donate part of the money given to them (whether to the government or to the control institution), while controlling for dissuasion (that is, without using any type of dissuasion). After making their decision concerning their donation, the participants answered a questionnaire, from which all data relevant for the study were gathered. The recruitment of 120 people required for the study was carried out by the company IMASEN, which belongs to the Peruvian Association of Business for Market Investigation (APEIM for its acronym in Spanish). For recruitment, the company applied a convenience sampling using the snowball methodology. Snowball sampling is a non-probability sampling technique used for identifying potential subjects who belong to the segment under study.

The population from which the sample was extracted included people between 25 and 55 years of age from all socioeconomic levels in the Lima Metropolitan Area; all individuals had the capacity to pay taxes and belonged to the economically active population (EAP). The details about the protocol of the experiment and the instructions given to the subjects can be checked in López-Pérez and Ramírez-Zamudio (2018). 


\section{Optimum sample size for the experiment}

As suggested by List, Sadoff and Wagner (2010), in order to discover the optimum sample size, the researcher may form beliefs regarding the variability of results between the treatment group (those individuals who decided to voluntarily give money to the Peruvian government) and the control group (those who decided to donate voluntarily to the Peruvian League against Cancer), which may, for example, originate from theory, previous empirical evidence, or a pilot experiment. The present study used a pilot experiment in order to evaluate differences in variations between the two groups and to discover the optimum sample size.

The researcher must also decide about the difference in the (average) donation between the treatment group and the control group $\left(\mu_{1}-\mu_{0}=\delta\right)$, which the experiment is designed to be able to detect at a significant level, as well as about the power of the test. Finally, the significance of the effect of treatment should be determined using a t-test.

In order to calculate the optimum sample size, it is necessary to specify a null hypothesis and a specific alternative hypothesis. The null hypothesis means that no treatment effect exists, that is, the average difference in donations between the two groups is equal to zero. The alternative hypothesis is that the treatment effect takes on a specific value. Choosing the optimum sample size in this scenario implies that the number of observations must be sufficient in order for the researcher to (i) reject the null hypothesis (when this is true) that the results of the treatment and control groups are equal, thus committing a type I error; and (ii) when the null hypothesis is false and the researcher does not reject it, which means committing a type II error.

Stated more formally, if the observations for both the treatment and the control groups are independentand $\mathrm{H} 0: \mu 0=\mu 1 \mathrm{yH} 1: \mu 0 \mathrm{P} \mu 1$, the difference in the sample average $\overline{Y_{1}}-\bar{Y}_{0}$ (which is not observed a priori) must satisfy the following conditions: a probability $\alpha$ of committing a type I error for a two-tailed test, that is, a significance level of $\alpha$. This is true if:

$$
\frac{\bar{Y}_{1}-\bar{Y}_{0}}{\sqrt{\frac{\sigma_{0}^{2}}{n_{0}}+\frac{\sigma_{1}^{2}}{n_{1}}}}=t_{\alpha / 2} \Rightarrow \bar{Y}_{1}-\overline{Y_{0}}=t_{\alpha / 2} \sqrt{\frac{\sigma_{0}^{2}}{n_{0}}+\frac{\sigma_{1}^{2}}{n_{1}}}
$$

Where $\sigma_{\mathrm{T}}^{2}$ and $\mathrm{n}_{\mathrm{T}}$ for $\mathrm{T}=\{0,1\}$ are variations conditioned on the result $\mathrm{y}$ and the sample size for the control and treatment groups, respectively. 
A probability $\beta$ of committing a type II error, that is, with a $1-\beta$ power for a two-tailed test. This is true if:

$$
\frac{\left(\overline{Y_{1}}-\overline{Y_{0}}\right)-\delta}{\sqrt{\frac{\sigma_{0}^{2}}{n_{0}}+\frac{\sigma_{1}^{2}}{n_{1}}}}=-t_{\beta} \Rightarrow \overline{Y_{1}}-\overline{Y_{0}}=\delta-t_{\beta} \sqrt{\frac{\sigma_{0}^{2}}{n_{0}}+\frac{\sigma_{1}^{2}}{n_{1}}}
$$

Equating (1) and (2), the following is obtained:

$$
\delta=\left(t_{\alpha / 2}+t_{\beta}\right) \sqrt{\frac{\sigma_{0}^{2}}{n_{0}}+\frac{\sigma_{1}^{2}}{n_{1}}}
$$

After a few trials testing the questions (to be understood by the subjects) and the protocol with students at the University of Lima, a pilot test was finally carried out with students in two classrooms. In each classroom, the same protocol and the same questionnaire were applied that we used later in the experiment: one class with donations to the government and the other to the Peruvian League against Cancer. The pilot test was not incentivized, but we did obtain differences in the donations. Given that the donations of the two groups were not equal, ${ }^{22}$ it was determined that the optimum sample size $\left(\mathrm{N}^{*}\right)$ is:

$$
N^{*}=\left(\frac{t_{\alpha / 2}+t_{\beta}}{\delta}\right)^{2} \sqrt{\frac{\sigma_{0}^{2}}{\pi_{0}^{*}}+\frac{\sigma_{1}^{2}}{\pi_{1}^{*}}}
$$

Where $\pi_{0}^{*}, \pi_{1}^{*}, \pi_{0}^{*}+\pi_{1}^{*}=1$ and $\mathrm{N}^{*}=\mathrm{n}_{0}^{*}+\mathrm{n}_{1}^{*}$. If sample sizes are large enough, normal distribution is a good approximation of distribution t. Likewise, if the variance of the results between the treatment and control groups are similar enough, a minor difference should exis ${ }^{23}$ between the optimum size of observations for the treatment group ( $\mathrm{n}_{1}^{*}$ ) and for the control group $\left(\mathrm{n}_{0}^{*}\right)$. According to standard literature with a significance level of 0.05 and a test power of 0.80 , values of $t_{\alpha / 2}=1.96$ and $t_{\beta}=0.84$ are obtained from normal standard tables. Using these values and the evidence in Table 1 that compares the (average) donation between the treatment and control groups, a value $\mathrm{N}^{*}=82$ is found.

22 The results of the pilot test indicate that the treatment and control groups have a standard deviation of 5.54 and 3.31, respectively.

23 Actually, when $\sigma_{0}^{2}=\sigma_{1}^{2}=\sigma^{2}$, then it is shown that $n_{0}^{*}=n_{1}^{*}=n^{*}$ (List, Sadoff \& Wagner, 2010). 
Table 7.

Results for the t-test for two samples with different variances

\begin{tabular}{|c|c|c|c|c|}
\hline Group & Observations & Average & $\begin{array}{c}\text { Standard } \\
\text { deviation }\end{array}$ & $\mathrm{H}_{0}: \mu_{1}-\mu_{0}=0$ \\
\hline Treatment & 30 & 6.50 & 5.54 & $\mathrm{H}_{1}: \mu_{1}-\mu_{0} \neq 0$ \\
\hline Control & 30 & 3.77 & 3.31 & $\operatorname{Pr}(|T|>|t|)=0.02$ \\
\hline Difference & & $\delta=2.73$ & & \\
\hline
\end{tabular}

Note: The results of the pilot test indicate that the hypothesis that the average of donations for both groups are statistically equal is rejected (with $5 \%$ significance).

Source: authors' elaboration.

To find observations $\mathrm{n}_{0}^{*}$ and $\mathrm{n}_{1}^{*}$, we use the procedure proposed by List, Sadoff and Wagner (2010). Since the ratio of standard deviation between both groups is $\sigma_{1} /$ $\sigma_{0}$, this variability enters in each group's observations. Thus, $\mathrm{n}_{1}^{*}$ must be 1.67 times more than $\mathrm{n}_{0}^{*}$, then the optimal number for the treatment and control groups are $\mathrm{n}_{1}^{*}=51$ and $\mathrm{n}_{0}^{*}=31$, respectively. Since we obtained enough resources to finance more subjects, we opted to form two groups of 60 individuals each, one for control and the other for treatment. 